\title{
Violent transfusions: strategies of and against immunity in contemporary Brazilian cinema
}

\author{
Ramayana Lira*
}

\begin{abstract}
Violence, in films, is often generated by an 'immunizing' logic, which according to Roberto Esposito, is typical of contemporary societies. Esposito says that the immunizing logic can be seen in State institution, laws, territorial organization or ethnic communities identified by a common element (language, religion, culture). These groups tend to shut out, immunizing against the 'outside' world. The films respond to the violent exclusion with a 'violent image' (not an 'image of violence', an image that presents itself as a correction of the world), a kind of violence that is a refusal of excluding violence. This 'violent image' is a line of flight that traverses many segments 'immunized' against what is 'strange' and 'foreigner', reestablishing the transit. This article questions how cinematographic discourse creates violent situations where spectators are challenged to face their own auto-immunization and called to reestablish the flux of violent images which are, above all, irradiation, explosion, contamination.
\end{abstract}

\section{Keywords}

Brazilian Cinema. Violence. Immunization.

Recently, Brazilian spectators have been bombarded with violent experiences Brazilian films are no exception for the ubiquity of violence. The controversy about Tropa de Elite/Elite Squad (José Padilha, 2007), exemplifies the relevance of the discussion for an understanding of contemporary Brazilian cinema. José Padilha's film, which won the 2008 Golden Bear at Berlin Festival, was highlighted by a number of popular publications such as weekly Veja, which pictured Tropa de Elite on its cover on 17th October 2007. The article is entitled "Pegou Geral", a double entendre that could

\footnotetext{
* Professora do Programa de Pós-Graduação em Ciências da Linguagem da Universidade do Sul de Santa Catarina.
} 
be translated as something that is successful - pegou ${ }^{1}$ - and as an expression of total control over a situation. The film is praised, on the cover, for its purported 'realism' in the depiction of Brazilian police and for a supposed 'fair' treatment of 'reality', as the cover announces that it treats "bandits like bandits" and denounces drug users as "partners" with drug dealers. This kind of critical reception calls attention to the closeknit association between box-office success and the rendition of a 'true' - and moralistic - view of the social malaises in contemporary Brazil.

Fairly recent films like Cidade de Deus/City of God (Fernando Meirelles, 2002) Carandiru (Hector Babenco, 2003), O Invasor/The Trespasser (Beto Brant, 2002), Amarelo Manga/Mango Yellow (Claudio Assis, 2002), Cidade Baixa/Lower City (Sérgio Machado, 2005), Tropa de Elite, Salve Geral/Time of Fear (Sérgio Rezende, 2009) are, in various degrees, committed to the exploration of the various facets of violence, often appealing to a pre-existing reality as form of cultural legitimation. This appeal is reinforced by strategies that are well accounted for by Ilana Feldman:

\begin{abstract}
Incorporating documental images and amateur records, making use of 'wilder' aesthetic codes - once a mark of modern cinema - as a new convention, reenacting given nonfictional events and often using high technological sophistication bestowed by digital technologies of recording and editing images and sounds in order to promote productions marked by a feel of improvisation, 'urgency', formal 'poverty' and 'amateurism', often simulating a spectacle that simulates its nonstaging. ( $\mathrm{p}$. 237) $)^{2}$
\end{abstract}

Whereas Feldman's research is concerned with the approximations between cinema and the audiovisual 'real' (mainly televisual, via reality shows), my concerns here are directed to the possibility of understanding violence as a political force that destabilizes political notions such as unified self, representation, agency, posing questions to the spectator which may counter the investment in cultural hegemonic processes of normal/t/ization of both self and society.

This problematic is addressed by a number of Brazilian scholars. Lúcia Nagib, for instance, in her recent A Utopia no Cinema Brasileiro/ Utopia in Brazilian Cinema, explores

O Invasor saying that although it is a work of fiction, it can "reveal" more than the document through critical analysis. In her discussion Nagib defends that Marina's character is, perhaps, the film's main revelation as a symptom of late capitalism ( $p$. 177). The trope of the revelation is textually present. And although Nagib's study of the fate of Utopia in Brazilian cinema questions the way contemporary films deal with

1 In Portuguese the verb pegar, informally, refers to something that becomes popular, for example a catchy tune ("Aquela música pegou", meaning 'that song became popular, everyone is singing it'). On the other hand, it also makes reference to a sudden assault, as in "a polícia pegou geral", that is, 'the police struck down".

${ }^{2}$ In the original: Incorporando imagens documentais e registros amadores, fazendo dos códigos estéticos mais 'selvagens', que um dia foram a marca de um cinema moderno, uma nova convenção, reencenando acontecimentos não-ficcionais já dados previamente e se utilizando, muitas vezes, da alta sofisticação tecnológica, oferecidas pelas tecnologias digitais de captação e finalização de imagens e sons, para promover produções marcadas por uma impressão de improviso, de 'urgência', de 'precariedade' formal e de amadorismo, muitas vezes, simulando um espetáculo que simule sua não-encenação. [my translation]. 
a national project, it eventually falls into a rather nonanalytical praise of filmmakers like Walter Salles and Fernando Meirelles, who have an 'international' career. She says: "If the Brazilian utopia is far from being realized, the Brazilian cinema utopia, at least in aesthetic terms, has taken place" (21)4. The cinematic utopia: the recognition in a world market and the capacity to talk about violence and social convulsion in a 'realist' way that is palatable for domestic and foreign audiences.

Esther Hamburger in "Violência e pobreza no cinema brasileiro recente"/"Violence and poverty in recent Brazilian cinema" analyzes contemporary films that stress the visibility of poor, black dwellers of slums and periphery. She argues that when television and cinema bring these subjects to public attention, they intensify and stimulate a struggle for the control of visibility, for the definition of which subjects and characters will have audiovisual expression. Her approach, however, deals in term of stereotypes - how to correct or diversify the production of the images of poor violent people. What such truth-oriented perspective neglects is the fact that what is said to be 'true' or not about a given community is not easily unveiled or wholly unproblematic.

A different account of the issues discussed here is given by Ismail Xavier. In "Da violência justiceira à violência ressentida"/"From punishing violence to resentful violence", he argues that contemporary films resist the temptation to romanticize criminals like works in the past. The objective is to undermine the criminal's representativity (as a 'spokes-person') in contrast with the violent characters of the past - mainly from the 1960's and 1970's - whose violence, although unequivocally criticized, still resounded as a justifiable response to social injustice. In this text, however, Xavier reveals a nostalgic reference to filmmakers of the 'past', as if they, like the criminals they produced on the screen, also held the legitimacy for social criticism. He states that

The 1960-70's metaphors transformed the rifle into a camera, the left-winged filmmaker into a proto-guerilla confronting the media, and associated the aesthetics of violence to the wars of national liberation. The emphasis now changes and introduces a cinema whose unfoldings are more problematic because this modern instrument can corrode relationships and has unpredictable consequences. (p. 66$7)^{3}$

What I find controversial about his argument is the qualification of recent works as "more problematic". This characteristic implies a 'less' problematic past, which would portray violence and poverty in a more 'adequate' way. To a certain extent, this is the same argument put forward by Ivana Bentes in her discussion of the 'cosmetics of violence' as opposed to the 'aesthetics of violence'. Bentes defends that recent Brazilian films are resuming Cinema Novo themes such as poverty and violence, but without the political inflection of social denounce. For Bentes, contemporary cinema,

${ }^{3}$ As metáforas dos anos 60-70 que transformavam a câmara num fuzil, o cineasta de esquerda num proto-guerrilheiro enfrentando a mídia, e associavam a estética da violência às guerras de libertação. A ênfase agora muda e entra em cena um cinema cujos desdobramentos são mais problemáticos, pois este instrumento moderno pode corroer relações e tem consequências imprevistas. 
on the contrary, makes a spectacle out of misery and violence, increasingly consumed as a "typical" or "natural", albeit helpless element (p. 243).

In her account, violence emerges as a new urban folklore, with its stories of crimes, massacres and horrors. A new 'brutality' that does not create spaces for complicity or mercy. Such random, meaningless violence eventually becomes a spectacle, representing the ultimate scission between favelas and the rest of the city. Moreover, there is no political discourse like in the 1960s (p. 249). What is different from the Cinema Novo context is the fact that presently the images of violence are also being appropriated by the marginalized subjects which conventional cinema demonizes. She concludes the article by stating that there are many aesthetics of violence, with diverse ethics and consequences: affirmative, reactive, resistant, they can be symptoms and expression of forms of living, valuing and thinking (p. 254). Although Bentes makes an important point by making reference to the different appropriations of images of violence, in these texts she stills reverberates the prominence of the 'images of violence' as a 'good' or 'bad' representation.

In dialogue with audiovisual forms such as Hollywood genre film and exploitive TV news programs, much of the recent productions has approached urban spaces through an allegedly 'realist' standpoint and were saluted as a 'rediscovery' of Brazilian society through which filmmakers exposed their 'critical social awareness'. The use of the expressions "reality" and "reveal" is pervasive when referring to the approach described here, indicating a belief in the possibility of a true 'revelation', of an objective expression of the world. Interestingly, in these circulating discourses about Brazilian films, the constructed 'reality' of the film is taken as 'reality' itself. We can refer to Fatima Toledo's collaboration in the preparation of actors for Cidade de Deus, Cidade Baixa, Tropa de Elite, among other contemporary films. In an interview entitled "Como não Ser Ator"/How not to be an actor to monthly Piauí magazine, Toledo defends that actors should not prepare for their roles according to Stanislavski's "What if...", which is based on the "possibility of not being" (54). $6^{5}$ She does not deny it that actors can "not be", but she argues that "being immediately awakens the sensorial. It's real! It's like in life!" $(54)^{6}$ For Toledo, people are becoming desensitized and the expression "What if..." serves as a sort of security device that prevents people from acting. This search for the 'real' is also present in her directorial debut and which, according to the Piauí article, is provisionally entitled Sobre a Verdade (On Truth).

Commonsense has it that representations of violence lead to moral indignation, to the valuing of the images as good or bad for its content, to the fate of the image as a 'correction' of the world; these are images of violence. The images of violence have an important political overtone, I want to argue, because they aim at conducting our bodies through preestablished, determined reactions. That means that the social and

\footnotetext{
4 See the covers of popular weekly publications in Brazil such as Veja 19.07.2006 and 10.01.2007, Isto É 24.01.2007, 05.07.2006 and 24.05.2006, Época 06.01.2007, 03.03.2006 and 18.05.2005, for examples of this discourse.

${ }^{5}$ Possibilidade de não ser. [my translation]

${ }^{6}$ O 'eu sou', por outro lado, desperta o sensorial imediatamente. É real! É como na vida! [my translation].
} 
moral 'denouncement' that tinges the films expresses a will to 'correct' the world, set it back to its 'proper' reality (always a 'slice' of the real, as argued above). Images become a piece of information, a "word of order", in Gilles Delueze's formula, a tool to construct reactions, to control de bodies, to police the spectator. What is at stake here is how we can conceive of images that are convoluted, in flux, in transit. The prefix trans-brings about the promise of passage, the debunking of essentialist positions, the possibility of becoming. In order to become other, these images cannot be stopped by the rhetoric of immunization. Here, a series of contemporary Brazilian films (I can cite Cidade de Deus, Carandiru, Cidade Baixa and Tropa de Elite as paradigms) can be thought as instances of control over this flux. Their images are immobilized through discourses of Naturalistic mimeticism, a "correction of the world", as I indicated above. Eventually, these films immunize as us against the force of the image. We are placated by denunciation and moral indignation.

When we map out the contemporary cinematographic production in Brazil we are able to see a profusion of films, either fictional or documentary, where violence is set in the city. In a sense, this production creates a false idea of causality: it is the city that generates the violence represented on the screen. The city becomes an exemplary camp, concentrating vices, miseries and failures. Zuenir Ventura's book Cidade Partida gives a literary example of how the 'fracture' can be seen. The book's theme is the division of the city of Rio de Janeiro into two parts: the welcoming touristic attraction and the hidden city of poor inhabitants, violence and drug trafficking. Ventura proposes that although rich and poor share a same urban milieu, they live as if it were two distinct cities.

Ventura's perception replicates theses put forward by the Social Sciences for 30 years or so. What the notion of the divided city fails to perceive is the flux between the poles, with micro interaction that go from the dissemination of funk music - originally associated with the favelas - into middle and upper-classes and the parodic appropriation of the brand Daslu - a high society store - by an organization of prostitutes who launched the brand Daspu, with its ironic resonance of the expression "das putas", i.e., "whores'". Nevertheless, the notion of a broken city still pervades Brazilian films, mainly in their depiction of urban spaces like the favela. The chasm between rich and poor, as described by Ventura, is reproduced in films, with the same inflection of insuperable separation. In this sense, both Ventura's book and contemporary Brazilain movies seem to be preserving some of the Naturalistic impulse that marked Brazilian literature in the second half of the 19th century.

In the novel O Cortiço/The Tenement (1890), for example, Aluísio de Azevedo creates 'a portrait' of Rio de Janeiro under strong urban changes:

That, by the way, did not prevent the small houses from emerging, one after the other, and soon being filled, spreading everywhere, from the shop to the hill, and then turning to Miranda's corner and advancing over his yard, which seemed threatened by that snake made of stone and whitewash. [...] And in that muddy and steamy land, in that hot and slimy humidity, there started to crawl, to simmer, to 
grow, a world, a living thing, a generation that seemed to sprout spontaneously, right there, from that slough, and multiply like maggots in manure. ${ }^{7}$

Literary language is engaged, in this extract, in the construction of an urban environment that would refer immediately to the 'real' conditions of a 19th century cortiço. Actually, Azevedo uses a legal maxim as an epigraph: "The Truth, the whole truth and nothing but the truth", stressing the author's program. Flora Sussekind argues, in Tal Brasil, qual Romance?/Like Brazil like Novel, that novels like O Cortiço seem to look for a meaning beyond itself, in the extra-literary context, reinforcing its being a document. She notes that it is not by chance that the novel makes reference to a Penal Law axiom, for "when a novel tries to hide its own fictionality in the name of a greater referentiality, perhaps its major models are science and journalistic information, as a rule considered paradigms of objectivity and truth $9^{8 \prime \prime}$ (37). A reader facing such artistic strategies tends to over-look the language that constructs the works, tracing direct parallels with the extra-textual world. Such strategies, Süssekind goes on, present continuities in literature produced in the 1880's, 1930's and 1970's. Such continuity, I would like to argue, can also be extended to a part of the production in contemporary Brazilian cinema. We can see a metaphor of this search for 'objectivity and truth' in a shot from Amarelo Manga, when the butcher played by Chico Diaz enters the decadent hotel carrying a huge piece of meat on his back. Here, the use of wide-angle lens extends the limits of the frame, including more information on the screen. A desire to show all, to see everything. Babenco's Carandiru is, to a certain extent, also a film about hearing and looking at, a film about who is allowed to hear and look, and who can be subjected to the gaze and hearing. It transforms the prison into a thin glass plate under the microscope. Actually, the film insists in framing things and people with a proliferation of small windows, grids, hatches, doors, gates. These little openings suggest both isolation from the prisoners and a desire to look, a will to know what they are like, mingling voyeuristic and controlling impulses with the caution against contagion.

In many cases, filmmakers would be legitimized by the 'delegation' of the subaltern's voice present in the films. Director Tata Amaral reveals the anxiety of reaching the 'truth' and the 'reality' of the characters in her film Antônia, in a text revealingly named "Em Busca do Naturalismo no Cinema"/In Search of Naturalism in the Cinema:

\footnotetext{
${ }^{7}$ O que aliás não impediu que as casinhas continuassem a surgir, uma após outra, e fossem logo se enchendo, a estenderem-se unidas por ali a fora, desde a venda até quase ao morro, e depois dobrassem para o lado do Miranda e avançassem sobre o quintal deste, que parecia ameaçado por aquela serpente de pedra e cal. (...) E naquela terra encharcada e fumegante, naquela umidade quente e lodosa, começou a minhocar, a esfervilhar, a crescer, um mundo, uma coisa viva, uma geração, que parecia brotar espontânea, ali mesmo, daquele lameiro, e multiplicar-se como larvas no esterco. [my translation].

8 Quando um romance tenta ocultar sua própria ficcionalidade em prol de uma maior referencialidade, talvez os seus grandes modelos estejam efetivamente na ciência e na informação jornalística, via de regra consideradas paradigmas da objetividade e da veracidade. [my translation].
} 
What I was searching for was the truth in the situations and emotions and they would not always correspond to what we imagined. More than imposing a story, I wanted them [the actors] to tell theirs. [...] That it would be like 'peeping' into those characters' lives, who are there independently of the camera. ${ }^{9}$

The choice of words is telling: when Amaral says "we imagined" (my emphasis), one can read the pronoun as a reference to a) the film crew and the director; $b$ ) filmmakers as a group from which Amaral is part; and c) the film's audience. We 'imagine', but it is more important to see what the "situations and emotions" are 'really' like. The access to this 'reality' is granted by the delegation of voice: because the stories are not mediated by the director/screenwriter, but are told by the actors themselves. The director seems to want to be the invisible medium through which these voices speak. Moreover, the will to 'peep' into ("dar uma espiada") the characters' lives indicates a desire to observe at a distance, because 'we' may not want to get too close, too familiar with these lives. Amaral, here, describes the impetus to film the nation as it is: like nation, like film.

In the chapter entitled "Do Naturalismo ao Realismo Crítico"/From Naturalism to Critical Realism, from the book O Discurso Cinematográfico, Ismail Xavier uses the term Naturalism in a broad sense, intersecting with the notion of literary Naturalism, but going beyond it. Xavier sketches the concept as an effort to faithfully reproduce the physical world and human behavior, as if the audience were directly in touch with the world. Filmic discourse would then be 'natural', a transparent medium revealing reality. The renewed interest for this kind of 'immediate' discourse is materialized in what Leonardo Mecchi calls 'Brazilian Popular Cinema' of the 21st century: in his article he surveys the top box office hits of the last eight years to reveal a tendency towards what he calls "film-verism" (filme-verismo), that is, the affirmation of cultural legitimacy by appealing to the representation of an aspect from our reality.

In filmic narratives since the 1990's, poverty and violence are consumed as 'typical' or 'natural' constituents: in such view there is nothing one can do about them. Ivana Bentes argues that these films "rarely present 'explanations' for any context, they do not intend to judge, perplex narratives, and pose as 'mirror' and 'cognizance' of a state of things"10 (249). The impulse towards 'reality', through artistic discourse, described by Süssekind as like Brazil, like novel ${ }^{11}$ (Tal Brasil, Qual Romance), contribute to the appeasement of contradictions and fractures. Like Naturalistic novels, it can be said that films such as Cidade de Deus, Cidade Baixa, Amarelo Manga tend to portray violence by appealing to a 'real' constructed as 'immediate', as if the

9 O que eu buscava era a verdade das situações e das emoções e estas nem sempre correspondiam ao que imaginávamos. Mais do que impor uma história, eu queria que eles contassem as deles [...] Que funcionasse como uma "espiada" na vida daquelas personagens que estão lá independentes da câmera. [my emphasis].

${ }^{10}$ Filmes que quase nunca se pretendem "explicativos" de qualquer contexto, não se arriscam a julgar, narrativas perplexas, e se apresentam como "espelho" e "constatação" de um estado de coisas. [my translation].

${ }^{11}$ The title of the book makes explicit reference to expressions of comparison such as like father, like son. According to Süssekind, the expression reveals pride in having a son, just like the father; indeed, it reveals the expectation that the son will mirror the father. Breaking with these bonds can be extremely traumatic. 
characters where directly 'denouncing' reality. Such search for 'the real' - that can also be perceived in the increasing production of documentaries - is, however, more often then not, coated with an aesthetic or narrative varnish to prevent from a traumatic encounter.

Among the many images of violence that pervade contemporary Brazilian cinema there is a strong tendency towards a 'bad encounter' between spectator and film. These images reinforce systems of thought based on dogmatic views of 'Brazilian reality and society'. They are entrapped in sadness and negativity. What I am interested in analyzing is exactly how we can go from one state to another. How, in many instances, the potential of the violent image is stopped by a belief in the image of violence as a final comment on 'reality', attempting to construe a consensus about what this reality is. Violence in films is, in this latter sense, at the service of a set of moral codes against which 'reality' is judged. Violence becomes a means towards an end.

For the Italian philosopher Giorgio Agamben, children play with whatever falls into their hand, transforming into toys things which belong to 'serious' spheres of life: law, economics, war. Their use of these things "does not coincide with utilitarian consumption" (76). This playful 'profanation' has to be differentiated from 'secularization'; the latter is a form of repression, because it simply replaces the forces it deals with, for example, displacing theological monarchy with worldly monarchy (77). Profanation deals with a different principle. It neutralizes what is profaned, destroying its aura and returning it to its use. As Agamben puts it: "both are political operations: the first guarantees the exercise of power by carrying it back to a sacred model; the second deactivates the apparatuses of power and return to common use the spaces that power had seized"(77). Returning violence to the 'common use', that is, its desacralization, implies rescuing it from capitalism's tendency to create a sphere of unprofanable things. This sphere has a lot to do with establishing ends for things. If things have an end, then they cannot be profaned.

A good example is that of a cat's behavior while playing with a ball of yarn. The instincts that would otherwise be employed in hunting a mouse, for example, are spent in a 'meaningless' task: hunting a ball of yarn. The play, then, "becomes a pure means, that is, a praxis that, while firmly maintaining its nature as a means, is emancipated from its relationship with an end; it has joyously forgotten its goal and can now show itself as such, as a means without an end" (86). Like the cat has found a new use for the ball of yarn, we must also think of new uses for violence that could defy its entrapment in some end. In this sense, 'profane' violence would be characteristic of the violent image, the image that plays with violence without being caught in a functionalist logic. Images of violence and violent images are, thus, two possible ways to approach films. The challenge is to structure a critical strategy for contemporary Brazilian films that could go through the mimetic impulses of the images of violence, to find in the violent images the openness that could propose ways of distributing the sensible other than those based on resentment and negativity. This potential would lie in the film's capacity to defy the limitations of the intellect, drawing us not to a chain of action and reaction, but to a zone of indeterminacy between 
perception and action, one that leaves us with no straight forward 'response' to the images.

In this perspective, the body no longer reassures reality, identities or self - on the contrary, it is exposed to variations, fluxes and mutations. This much more complex understanding of what a body can do surpasses the widespread simplification that 'the body thinks'. What this platitude fails to perceive is that the variations and intensities that traverse the body force us to think about something that, from its origins, belongs to the sphere of the unthinkable.

Images of violence, thus, represent an impediment to theses fluxes. They are paralyzed by their function as comments about reality. They 'immunize' us against the uncertainties, ambiguities and contaminations that can be found in violent images. Immunization is what happens when spectators are sheltered under the images of violence and their reference to a normal/t/ize 'real'.

For Italian philosopher Roberto Esposito, immunity has a double meaning: it imports the exemption of an obligation and a privilege. One is immune as long as $\mathrm{s} / \mathrm{he}$ is exempt from an obligation other people have. The munus (obligation, debt, work) is a comparative concept, because it involves the others. So much so that Esposito will defend the notion that the counterpart for immunitas is not the absence of munus, but the community of those who have it (Immunitas 15). The munus has important political connotations, as it signifies an obligation to the other.

The contiguous relationship between communitas and immunitas means that the latter is not a simple negation of the former, a protection from what is external, but it is inscribed in the horizon of the common munus. Immunity, then, is a dispensation of the reciprocal gift-giving, creating a sphere of what is 'proper', individual, against the communal. This exoneration is necessary for the very existence of community - in a sense, community has to protect itself from an excess of munus. What follows is that community puts itself in danger by introjecting immunity in its core, much similarly to the working of vaccines: the inoculation of a small dosage of a dangerous element in order to prevent the development of a disease.

According to Esposito, we have, on the one hand, an institutional apparatus of juridical forms, which springs from the State, and, on the other, territorial organizations, ethnic communities, identified by a common element, be it territory, language, religion or culture. These groups, defined in territorial or cultural terms, tend to shut off, immunizing against exterior elements. In spite of the fact that this destructive dialectics between ' $\mathrm{I}$ ' and 'Other' still determines the sociopolitical dynamics around the world, subjectivity is all about flux, a fact that modern society tried to erase. The idea of the 'foreign' takes on a connotation of social, symbolic, medical danger, risk, ensuing the immunological perception of the 'other' as contagion, contamination. The other as infection, a (self)destructive perception. Esposito argues that the immunitarian system is both an offensive and a defensive dispositive against what cannot be recognized as 'one's own'. This dispositive, when taken to its limits, tends to revert against what it was defending, as an 'auto-immune' disease, determining the implosion of the whole organism (29). 
But we can also find an affirmative stance through the lens of immunity, in the light of Roberto Esposito's elaboration of a positive immunity in the relationship between mother and fetus. This relationship is the proof that immunity does not inevitably deteriorate into a suicidal auto-immunity crises. In Immunitas, Esposito discusses the imperative of security that overwhelms contemporary social systems and the process by which risk and protection reinforce each other. Esposito explains:

The negative protection of life, strengthened so much that it is reversed into its own opposite, will wind up destroying not only the enemy outside it but also its own body. The violence of interiorization - the abrogation of the outside, of the negative could be reversed into an absolute exteriorization, in a complete negativity. ("Immunization and violence", 11)

It takes a new vocabulary for (re)assessing the boundaries between life and its other, a new vocabulary that recognizes the one in the other such that any living being is thought in the unity of life, in a co-belonging with what is different. The immunity system of a pregnant mother serves as a model for Esposito, who says that

women develop certain types of antibodies which, by hiding the symptoms of the presence of extraneous agent coming from the fetus, allow the mother to survive. [...] In short, immunizing against the other [the fetus], the mother immunizes against herself. She immunizes herself against an excess of immunization ${ }^{12}$. (242)

The mother's body does attack the fetus but the immunological reaction ends up protecting the fetus and not destroying it. Pregnancy gives an example of a productive immunitarian existence, where difference and confrontation are not necessarily destructive (243).

Most images of violence reinforce the biopolitical paradigm of immunization, and like a mother's body, we must find ways to immunize ourselves against the excess of immunization - perhaps, I would risk saying, by opening up to the violent image. Violence seems to be at its strongest political potential when it explodes the clichés in the images and punctures the immunizing bubble around us. When it injects us against immunization. It is dissemination, contamination, transfusion, restoring a force to the films that is welcome in out times of spectacular violence

Maybe this is a valid strategy to escape the pitfalls of approaching violence in contemporary Brazilian films as pronouncements about a reality that is too fleeting to be accounted for. The flow of images, of filmic spaces, of characters, of linguistic features indicate an alternative to the Naturalistic aesthetics that pervades Brazilian films centered on violence.

Let's briefly take Ruy Guerra's Estorvo/Burden for example. It is based on a novel by Chico Buarque, first published in 1991. Both works are non-linear narratives

12 This is my version of the Spanish translation, which reads: Las mujeres desarrollan determinados tipos de anticuerpos, lo cuales, al ocultar las siñales de pesencia de um agente extraño porvenientes del feto, permiten que sobreviva. [...] em síntesis, inmunizando de lo outro, también inmuniza de si. Se inmuniza de um excesso de inmunización. 
about a man who thinks he is being chased by strangers; and in the process of running away from his persecutors, he bumps into a number of character for whom he becomes a burden. The book begins with a circular sequence of words: "burden, to burden, extubare, disturb, perturbation, bewilderment, turbid, whirling, turbulence, turmoil, trouble, trap, hustle, crowd, slumber, stupor, cripple, uprising, insubordination, burden". ${ }^{13}$ Such sequence announces the dissolution of narrative line through the immersion in unique space and time. Much like the protagonist, lost in perambulations across the city, readers/spectators are thrown into discontinuous space and time. The main character's deambulatory walk is marked by the subversion of temporal structures - past, present and future are intertwined -, resulting in a 'burdened' film, which denies easy gratification.

Erratic time and space are reinforced by the fact that director Ruy Guerra opted to pulverize the imaginary city in Estorvo by filming in three different countries: Brazil (Rio de Janeiro), Cuba (Havana) and Portugal (Lisbon). The protagonist's wandering in these nameless spaces destroys the possibility of reconstructing both the geography and the history of the cities; here, the expression to err has a double meaning: the perambulation through unidentified streets also connotes being equivocated in relation to the spaces one circulates in; it means being lost, confounding spaces. It is only symptomatic that during the sequence in which the protagonist meets his sister for breakfast, she shows him pictures of unidentified places, which look interchangeable. His gaze gets lost in those places, so that there is no reason to look for meaning: his is a gesture of refusal to decide whether those are real places, actual representations. As spectator we are also driven to err(or) - our gaze also becomes convulsive.

Furthermore, the character's deambulatory walk links very diverse spaces: decadent deteriorated building, modern shopping malls, mansions, abandoned farmsteads. This shifting of spaces resounds on other 'displacements', as, for example, in the film's linguistic politics. Jorge Perugorría, the lead Cuban actor, speaks Portuguese with a strong Spanish accent and talks to other characters in both Spanish and Portuguese. Moreover, Ruy Guerra's voice over narration is marked by an undisguiseable Mozambican accent. The 'natural' convention that identifies territory with language is, thus, contested, for the expression in the different linguistic forms happens independently of the places where they are presented.

As a schizophrenic stroller, the main character in Estorvo opposes the rationality and utilitarianism of contemporary life, where acts must be justified according to their pertinence to social order. His is not, however, a flâneur. The flâneur tries, to a certain extent, to tame the frenzied rhythm of the historical moment he lived in. His slow strolls across the city, aiming at apprehending the city and its types, contrasted with the hubbub of metropolitan life. Contrary to the flâneur, however, in Estorvo we have a hiker whose walk is convulsive, because of his persecutory delirium. His total immersion in the fragmented space differs from the flâneur's detachment and epistemological confidence. Also, the use of closer framing and erratic camera

13 Estorvo, estorvar, exturbare, distúrbio, perturbação, torvação, turva, torvelinho, turbulência, turbilhão, trouble, trápola, atropelo, tropel, torpor, estupor, estropiar, estrupício, estrovenga, estorvo. [my translation]. 
movement (which follows the character's eye line) and the small number of longer framings prevent the spectator from apprehending the space more thoroughly. The image created, thus, puts us in an uncomfortable position: like the protagonist, we see, but we cannot fully map out what we are seeing.

Naming spaces so that they can be recognized in our fantasy has been a dominant strategy in spatial representation, which can be considered coherent with the efforts to delineate the 'national' as a counterpoint to the 'foreign'. But in Guerra's film what we have is a violent, debased universe that puts together the 'Third' (Cuba and Brazil) and the 'First' (Portugal) worlds. The film destabilizes the notions of 'belonging' to a nation.

Estorvo, thus, makes use of a series of violent images that call for interpretations that go beyond the current hegemonic terms employed in the discussion of violence in Brazilian films. The constant reference to an alegorical national identity, the reference to a divided urban space that stands for the chasm between rich and poor, the understanding of violence on the screen as a reflection, or the cause, of violence in 'real' life are all reductions of the political potential of violent images. The potential to contaminate us.

Cinema is the place where we can (re)imag(in)e violence in its destructive and constructive impulses. It is a safe place for these experiments. I never got hurt from watching violent films where people were dismembered. Not 'physically' hurt, that is. In my imagination I was often sad for a world where people had to die. Sad, I now risk a hypothesis, because those images where like aborted infants or rejected transplanted organs. Narrative closure and common sense logic produced their antibodies, so that they would not be attacked by the very violence that inhabited them.

\section{References}

AGAMBEN, Giorgio (2007). Profanations. New York: Zone Books.

AMARAL, Tata. "Em Busca do Naturalismo no Cinema". Pressbook for the film Antônia. 08 July 2008.

<http://antoniaofilme.globo.com/dowld/PRESSBOOK_PORTUGUES_2007.pdf>

AZEVEDO, Aluísio. O Cortiço. 22 Sep 2008. <http://www.dominiopublico. gov.br/download/texto/bv000015.pdf>

BENTES, Ivana. "Estéticas da Violência no Cinema". 24 March 2008.

www.eco.ufrj.br/semiosfera/anteriores/especial2003/conteudo_ibentes.htm

BUARQUE, Chico (1991). Estorvo. São Paulo: Cia das Letras.

DELEUZE, Gilles. "O Ato de Criação". Blog Intermídias. 12 Sep 2008.

<http://intermidias.blogspot.com/2007/07/o-ato-de-criao-por-gilles-deleuze.html> 
ESPOSITO, Roberto (2005). Immunitas. Buenos Aires, Amorrortu.

---. "Immunization and Violence". 16 Oct 2008.

http://www.biopolitica.cl/docs/Esposito_Immunization_Violence.pdf

FELDMAN, Ilana (2008). "O Apelo Realista: Um Expressão Estética da Biopolítica". Esther Hamburger, Gustavo Souza, Leandro Mendonça, Tunico Amâncio eds. Estudos de Cinema Socine. São Paulo: FAPESP, Annablume, Socine. 235-246.

FRAIA, Emilio. "Como não Ser Ator". Piauí Jan 2009: 54-58.

HAMBURGER, Esther (2007). "Vilência e Pobreza no Cinema Brasileiro Recente". Novos Estudos. 79: 113-120.

\section{Resumo}

Violência, nos filmes, geralmente é gerada por uma lógica "imunizadora", que, de acordo com Roberto Esposito, é típica das sociedades contemporâneas. Esposito diz que a lógica imunizante pode ser vista em instituições estatais, no direito, na organização territorial ou comunidades étnicas identificadas por elemento em comum (linguagem, religião, cultura). Tais grupos tendem a se isolar, imunizando-se contra o mundo "de fora". Os filmes respondem à exclusão violenta com uma "imagem violenta" (e não uma "imagem da violência", que se apresenta como uma correção do mundo), um tipo de violência que é uma recusa da violência excludente. Essa "imagem violenta" é uma linha de fuga que atravessa muitos segmentos "imunizados" contra o que é "estranho", "estrangeiro", reestabelecendo o trânsito. Este artigo questiona como o discurso cinematográfico cria situações violentas onde os espectadores são desafiados a encarar sua própria auto-imunização e chamados a re-estabelecer o fluxo violento da imagem que é, antes de tudo, irradiação, explosão, contaminação.

Palavras chave

Cinema Brasileiro. Violência. Imunização. 